(C) 2014

Конопля Н. И., доктор сельскохозяйственных наук,

Маслиёв С. В., кандидат сельскохозяйственных наук

Луганский национальный университет им. Тараса Шевченко

\title{
ВЛИЯНИЕ ОБРАБОТКИ ПОЧВЫ НА ВОДНО-ФИЗИЧЕСКИЕ ПОКАЗАТЕЛИ ЕЕ ПЛОДОРОДИЯ И УРОЖАЙНОСТЬ ПИЩЕВЫХ ПОДВИДОВ КУКУРУЗЫ
}

\author{
Рецензент - доктор сельскохозяйственных наук М. В. Орешкин
}

Подано результати багаторічних дослідів впливу основного обробітку грунту, зокрема полищевої й безполицевої оранки на 22-24 см та мілкого обробітку грунту на 10-12 см в поєднанні з однією, двома та трьома весняними допосівними культиваціями на динаміку запасів продуктивної вологи й водостійких агрегатів, його структуру, об'ємну масу й твердість. Рекомендовані сільськогосподарські машини для мілкого обробітку грунту та полицевої й безполицевої оранки. Надані рекомендації по внесенню мінеральних добрив та строків сівби. Наведено урожайність початків иукрової та зерна розлусної кукурудзи. Зроблений аналіз динаміки відхилення в залежності від виду обробітку грунту та ї̈ глибини.

Ключові слова: обробіток трунту, продуктивна волога, атретатний склад, об'ємна маса, твердість, иукрова ци розлусна кукурудза, урожайність.

Постановка проблемы. Последние годы в степных зонах Украины существенно расширились площади посевов пищевых подвидов кукурузы, в частности сахарной, лопающейся, кремнистой, восковидной и других, из которых изготовляют свыше 600 наименований продуктов питания. Однако начало широкого возделывания этих подвидов кукурузы вызвало множество вопросов в технологии ее возделывания, в частности в системах обработки почвы, сроках сева и т. д.

Анализ последних исследований и публикаций по данной проблеме. При выращивании пищевых подвидов кукурузы приемам основной и допосевной обработки почвы принадлежит главнейшая роль в создании благоприятных условий роста и развития культурных растений $[6,10,11]$.

Научной основой при выборе способов, глубины и системы обработки почвы служат агрофизические свойства плодородия почвы, в частности ее структура, объемная масса, твердость, водопроницаемость и другие показатели, которые регулируются почвообрабатывающими машинами и орудиями $[7,10]$. Им принадлежит главнейшая роль в создании благоприятного водно-воздушного и пищевого режимов, заделке растительных остатков, уничтожении сорной растительности, снижении численности вредителей и болезней кукурузы [10].

Ряд иследователей указывает, что приемы основной обработки почвы под кукурузу на пищевые и кормовые цели не отличаются $[4,5,8]$. В то же время многие другие опыты указывают на существенные различия в приемах основной и, особенно, допосевной обработок почвы при выращивании кормовых (зубовидной и кремнисто-зубовидной) и пищевых (сахарной и лопающейся) подвидов кукурузы $[2,6,9,11]$.

Некачественное проведение или формальное перенесение приемов основной и допосевной обработки почвы под сахарную и лопающуюся кукурузу с технологий выращивания зубовидной на кормовые цели приводило к потерям от 13 до $58 \%$ урожая $[2,6]$.

Но, несмотря на это, вопросы основной и допосевной обработки почвы под пищевые подвиды кукурузы, в частности сахарную и лопающуюся, остаются изученными недостаточно, а данных о влиянии на водные и физические свойства практически не имеется.

Цели исследований. Нами изучалось комплексное влияние основной и допосевной обработки почвы на агрофизичекие показатели ее плодородия и урожайность сахарной и лопающейся кукурузы на пищевые цели в Левобережной части северной Степи Украины.

Задачи исследований. Показать результаты многолетних опытов влияния основной обработки почвы, в частности отвальной и безотвальной вспашки на 22-24 см и мелкой обработки почвы на 10-12 см в сочетании с одной-тремя допосевными культивациями на динамику запасов продуктивной влаги и водостойких агрегатов, ее структуру, объемную массу и твердость. Сделать выводы и дать предложения по оптимальной обработке почвы исходя из проведенных исследованний.

Объекты, методика и условия проведения исследований. Опыты проводились в течение 2006-2012 гг. у Старобельском опытном хозяйс- 


\section{СІЛЬСЬКЕ ГОСПОДАРСТВО. РОСЛИННИЦТВО}

тве ЛНУ имени Тараса Шевченко и агропредприятии «Агро-бутово». Почвы опытных участков - черноземы типичные с содержанием гумуса в пахотном слое 3,5-3,6 \%, гидролизованного азота - 10,4-11,2 мг, подвижного фосфора $10,1-10,8$ мг, обменного калия - 14,4-15,3 мг на 100 г почвы. Предшественником кукурузы была пшеница озимая после пара. Вспашку почвы проводили плугом ПЛН-4-35, плоскорезное рыхление - КПУ-200, мелкую обработку почвы БДТ-3,0, допосевные культивации - КПС-4,0. Удобрения нормой $\mathrm{N}_{60} \mathrm{P}_{60} \mathrm{~K}_{40}$ вносили под основную обработку почвы и как подкормку. Сев кукурузы проводили при прогревании 0-10 см слоя почвы до $12-14{ }^{\circ} \mathrm{C}$. Высевали гибрид сахарной кукурузы Ароматная, лопающейся - Днепровский 925. Густоту стояния растений формировали из расчета 50 тыс./га. Междурядные культивации осуществляли в фазу 4-5 и 7-8 листьев у кукурузы. Закладку опытов, учеты, наблюдения проводили по общепринятым и специальным методикам [1, 3].

Результаты исследований показали, что при выращивании пищевых подвидов кукурузы различные способы и глубина основной и весенней обработки почвы существенно влияли на изменение ее водно-физических показателей. Прежде всего важнейшим фактором получения стабильно высоких урожаев в Степи Украины было накопление и сохранение осенне-зимне-весенней влаги. Главным водорегулирующим способом в технологии выращивания кукурузы была как основная, так и допосевная обработки почвы.

Весной, перед началом полевых работ, на участках, обработанных на глубину 22-24 см отвальными и безотвальными орудиями, накапливалось на 8-11 мм влаги больше, чем по мелкой (на 10-12 мм) обработке. В засушливые годы эта разница была еще большей и достигала 12-17 милиметров.

На момент сева кукурузы, несмотря на некоторое снижение влажности почвы, от первого срока сева в конце апреля при одной допосевной культивации до последнего срока сева в конце мая и 3-х допосевных культиваций, влажность посевного слоя почвы оставалась достаточной для получения всходов кукурузы, роста и развития растений в первые периоды вегетации (табл. 1).

Такое распределение влаги в почве было связано со строением пахотного и метрового слоев почвы. Данные сухого рассева почвы показали, что удельная масса агрономически ценных агрегатов размером 0,25-10 мм была наибольшей (66-72\%), а пылеватых частиц - наименьшей (11-17 \%) по плоскорезанной обработке с одной допосевной культивацией. По вспашке и мелкой обработке количество агрономически ценных агрегатов было одинаковым (65-70 \%).

Увеличение количества допосевных культиваций с одной до трех несколько ухудшало структурность верхнего 0-10 см слоя почвы и приводило к уменьшению агрономически ценных агрегатов по вспашке на 22-24 см в среднем на $6,1 \%$, плоскорезному рыхлению - на 7,8 \%, мелкой обработке почвы на 10-12 см - на 5,7-7,3\% и увеличению пылеватых частиц (менее 0,25 мм) на $4,8,5,4$ и $8,5 \%$ соответственно. Коэффициент структурности по плоскорезному рыхлению достигал, соответственно, 0,8, вспашке - 0,7, мелкой обработке $-0,6$.

Некоторые различия в агрегатном составе посевного слоя почвы по годам исследований определялись, очевидно, различиями во влажности почвы на момент ее обработки и наличием разного количества пожнивно-корневых остатков.

Содержание водопрочных агрегатов размером более 0,25 мм в посевном слое почвы перед посевом кукурузы наибольшим было по вспашке и достигало $56,3 \%$, тогда как по плоскорезному рыхлению $48,5 \%$, а по мелкой обработке - лишь 43,3 \%. Водопрочных агрегатов размером 0,25-1,0 мм также было наибольшим по вспашке, а наименьшим - по мелкой обработке почвы (табл. 2).

От сева к уборке количество водопрочных агрегатов по вспашке уменьшалось на $12,7 \%$, по плоскорезной - на $5,9 \%$, тогда как по мелкой обработке разрушение водопрочной структуры происходило несколько медленнее, и количество водопрочных комочков почвы уменьшалось лишь на 2,3 \%. Изменение водопрочной структуры почвы от сева к уборке кукурузы просходило главным образом за счет уменьшения комков размером 3,0-1,0 мм и (в меньшей степени) за счет агрегатов более 3,0 мм и 1,00,25 мм. Разрушение их происходило, очевидно, под воздействием посевных и почвообрабатывающих машин и орудий, а также осадков и других экологических факторов.

Объемная масса и твердость 0-10 см слоя почвы на всех делянках опыта находились в оптимальных

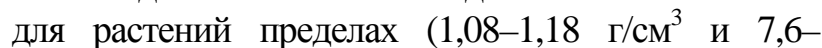

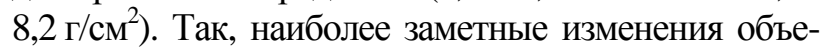
мной массы и твердости почвы наблюдались у верхнем 0-10 см слое почвы, где перед посевом кукурузы объемная маса по вспашке и плоскорезному рых-

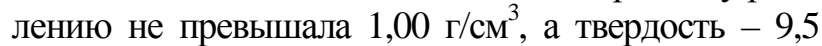

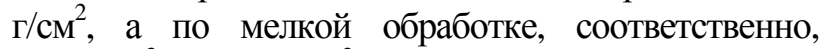
1,10 г $/ \mathrm{cm}^{3}$ и 10,3 г/ $\mathrm{cm}^{2}$, тогда как перед уборкой по вспашке и плоскорезному рыхлению были, соответственно, 1,23-124 и 20,2-20,4, а по мелкой обработке $-1,26 r / \mathrm{cm}^{3}$ и $23,0 \mathrm{r} / \mathrm{cm}^{2}$.

В 10-20-сантиметровом слое почвы по вспаш- 


\section{СІЛЬСЬКЕ ГОСПОДАРСТВО. РОСЛИННИЦТВО}

ке и плоскорезанной обработке от посева до уборки объемная масса увеличивалась с 1,20-

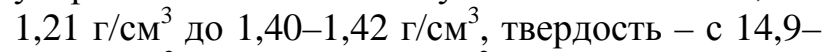

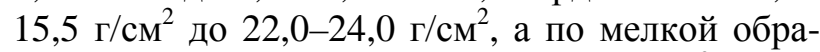

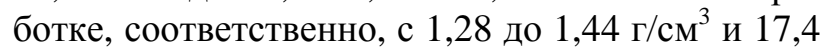

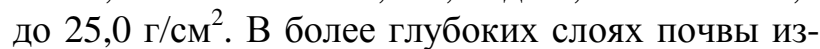
менения объемной массы и твердости почвы по вариантам ее обработки были незначительными.

Существенное влияние системы обработки почвы оказывали и на урожайность кукурузы. Так, вспашка на 22-24 см в сочетании с несколькими допосевными культивациями обеспечивала не только быстрый рост и развитие растений, образование большей листовой поверхности, но и формирование максимальной урожайности. Во влажные годы урожайность зерна лопающейся кукурузы достигала 3,21-3,97 т/га, початков сахарной - 10,0-12,0 т/га, а в засушливые - 2,20-
2,47 и 6,50-7,00 т/га соответственно.

Замена вспашки плоскорезным рыхлением на ту же глубину не давала положительных результатов: урожайность зерна лопающейся кукурузы в среднем достигала лишь 2,32-2,59 т/га, а сахарной 6,58-9,62 т/га, или на 0,25-0,29 т/га и 0,66-0,95 т/га меньше, чем по вспашке. Еще меньшей (1,372,17 и 6,11-8,99 т/га) урожайность зерна и початков кукурузы была при проведении мелкой обработки почвы на 10-12 сантиметров.

Уменьшение количества допосевных культиваций с двух-трех до одной и сев кукурузы в ранние сроки был неэффективным, так как урожайность зерна лопающейся и початков сахарной кукурузы, независимо от способа и глубины основной обработки, была наименьшей и не превышала в среднем 1,37-2,28 и 6,11-7,24 т/га (табл. 3).

\section{1. Динамика запасов продуктивной влаги в почве в зависимости от глубины и способа ее обработки, 2006-2008 z2.}

\begin{tabular}{|c|c|c|c|c|c|c|}
\hline \multirow{3}{*}{$\begin{array}{c}\text { Способы основной } \\
\text { обработки }\end{array}$} & \multirow{3}{*}{$\begin{array}{l}\text { Количество } \\
\text { допосевных } \\
\text { культиваций } \\
\end{array}$} & \multirow{3}{*}{$\begin{array}{l}\text { Срок сева } \\
\text { кукурузы }\end{array}$} & \multicolumn{4}{|c|}{ Запасы влаги, мм, перед: } \\
\hline & & & \multirow{2}{*}{$\begin{array}{l}\text { началом по- } \\
\text { левых работ }\end{array}$} & \multicolumn{3}{|c|}{ посевом кукурузы в слое } \\
\hline & & & & $0-10 \mathrm{~cm}$ & $10-20 \mathrm{~cm}$ & $0-100 \mathrm{~cm}$ \\
\hline \multirow{3}{*}{$\begin{array}{c}\text { Вспашка } \\
\text { на 22-24 см }\end{array}$} & 1 & 30.04 & 153 & 12,1 & 20,8 & 149 \\
\hline & 2 & 10.05 & 153 & 10,8 & 19,8 & 145 \\
\hline & 3 & 20.05 & 153 & 9,6 & 18,1 & 141 \\
\hline \multirow{3}{*}{$\begin{array}{c}\text { Плоскорезная } \\
\text { обработка } \\
\text { на 22-24 см }\end{array}$} & 1 & 30.04 & 157 & 14,0 & 21,2 & 156 \\
\hline & 2 & 10.05 & 157 & 13,3 & 20,6 & 152 \\
\hline & 3 & 20.05 & 157 & 11,9 & 18,6 & 149 \\
\hline \multirow{3}{*}{$\begin{array}{c}\text { Мелкая обработка } \\
\text { на 10-12 см }\end{array}$} & 1 & 30.04 & 142 & 13,6 & 20,1 & 141 \\
\hline & 2 & 10.05 & 142 & 12,8 & 19,6 & 136 \\
\hline & 3 & 20.05 & 142 & 11,4 & 17,8 & 135 \\
\hline
\end{tabular}

2. Содержсание водопрочных агрегатов в 0-10 см слое почвы (\%) перед посевом кукурузы в зависимости от глубины и способов основной обработки почвы

\begin{tabular}{|c|c|c|c|c|c|}
\hline \multirow{2}{*}{$\begin{array}{c}\text { Способы и глубина } \\
\text { обработки почвы }\end{array}$} & \multicolumn{5}{|c|}{ Размер водопрочных агрегатов, мм } \\
\hline & $\geq 3,0$ & $3,0-1,0$ & $1,0-0,25$ & $\leq 0,25$ & всего $\geq 0,25$ \\
\hline \multicolumn{6}{|c|}{ Перед посевом кукурузы } \\
\hline $\begin{array}{c}\text { Вспашка } \\
\text { на 22-24 см }\end{array}$ & 3,5 & 8,6 & 40,1 & 43,7 & 56,3 \\
\hline $\begin{array}{c}\text { Плоскорезная обработка } \\
\text { на 22-24 см }\end{array}$ & 3,1 & 6,6 & 38,8 & 51,5 & 48,5 \\
\hline $\begin{array}{c}\text { Мелкая обработка } \\
\text { на } 10-12 \text { см }\end{array}$ & 2,0 & 5,6 & 35,7 & 56,7 & 43,3 \\
\hline \multicolumn{6}{|c|}{ Перед уборкой кукурузы } \\
\hline $\begin{array}{c}\text { Вспашка } \\
\text { на 22-24 см }\end{array}$ & 1,5 & 4,3 & 37,8 & 56,4 & 43,6 \\
\hline $\begin{array}{c}\text { Плоскорезная обработка } \\
\text { на 22-24 см }\end{array}$ & 1,6 & 5,8 & 35,2 & 57,4 & 42,6 \\
\hline $\begin{array}{c}\text { Мелкая обработка } \\
\text { на } 10-12 \text { см } \\
\end{array}$ & 1,5 & 5,5 & 34,0 & 59,0 & 41,0 \\
\hline
\end{tabular}


СІЛЬСЬКЕ ГОСПОДАРСТВО. РОСЛИННИЦТВО

\section{3. Влияние способов основной и допосевной обработки почвы на урожайность зерна лопающейся и початков сахарной кукурузы (m/za), 2010-2012 22.}

\begin{tabular}{|c|c|c|c|c|c|c|}
\hline \multirow[t]{3}{*}{ Основная обработка почвы } & \multicolumn{3}{|c|}{$\begin{array}{c}\text { Зерно лопающейся } \\
\text { кукурузы* }\end{array}$} & \multicolumn{3}{|c|}{$\begin{array}{c}\text { Початки молочного состояния } \\
\text { сахарной кукурузы }\end{array}$} \\
\hline & \multicolumn{6}{|c|}{ количество допосевных культиваций } \\
\hline & 1 & 2 & 3 & 1 & 2 & 3 \\
\hline Вспашка на 22-24 см & 2,28 & 2,61 & 2,88 & 7,24 & 9,48 & 10,6 \\
\hline $\begin{array}{c}\text { Плоскорезное рыхление } \\
\text { на 22-24 cм } \\
\end{array}$ & 2,03 & 2,32 & 2,59 & 6,58 & 8,75 & 9,62 \\
\hline Мелкая обработка на 10-12 см & 1,37 & 1,78 & 2,17 & 6,11 & 8,20 & 8,99 \\
\hline $\begin{array}{l}\mathrm{HCP}_{005} \text { для основной } \\
\text { обработки почвы }\end{array}$ & \multicolumn{3}{|c|}{0,33} & \multicolumn{3}{|c|}{0,55} \\
\hline $\begin{array}{c}\mathrm{HCP}_{005} \text { для допосевных } \\
\text { культиваций }\end{array}$ & \multicolumn{3}{|c|}{0,26} & \multicolumn{3}{|c|}{0,74} \\
\hline
\end{tabular}

Негативное влияние уменьшения глубины основной обработки почвы с 22-24 см до 10-12 см и количества допосевных культиваций с трех до одной особенно сильно проявлялось в засушливые годы, когда урожайность зерна кукурузы уменьшилась до $0,87-1,29$ т/га, а початков молочной спелости - до 3,25-4,50 т/га.

Выводы. В современных технологиях возделывания пищевой кукурузы выбор глубины и способа обработки почвы должен базироваться

\section{БИБЛИОГРАФИЯ}

1. Вадюнина А. Ф. Методы исследования физических свойств почв. - 3-е изд. перераб. и доп. / А. Ф. Вадюнина, 3. А. Корчагина. - М. : Агропромиздат, 1986. - $416 \mathrm{c}$.

2. Гайтлин Й. Влияние технологических мероприятий на использование производственных потенциалов Бц гибридов кукурузы / Й. Гайтлин, К. Пуцарич // Советско-югославский симпозиум по кукурузе. - Харьков, 1985. - С. 90-103.

3. Доспехов Б. А. Методика полевого опыта / Б. А. Доспехов. - М. : Агропромиздат, 1986. $351 \mathrm{c}$.

4. Зубенко В. Х. О расширении производства сахарной кукурузы на Северном Кавказе / В. Х. Зубенко // Кукуруза. - 1965. - № 12. C. 35-36.

5. Кiвер B. X. Основні прийоми і засоби підвищення врожайності цукрової кукурудзи в умовах зрошення / В. Х. Ківер, М. I. Конопля, I. М. Семеняка // Вісник аграрної науки. 1996. - № 5. - C. 99-105. на учете водно-физических ее свойств. На черноземных почвах Левобережной части северной Степи Украины у полевых севооборотах наиболее эффективным является применение вспашки на 22-24 см в сочетании с тремя допосевными культивациями, обеспечивающими наилучшие водно-физические показатели плодородия почвы, а также получение максимальной урожайности зерна лопающейся и початков молочного состояния зерна лопающейся кукурузы.

6. Конопля M. I. Розлусна кукурудза на Сході України / М. І. Конопля, С. В. Маслійов. Луганськ : Шлях, 1999. - 155 с.

7. Медведев В. В. Оптимизация агрофизических свойств черноземов / В. В. Медведев. - М. : Агропромиздат, 1988. - $158 \mathrm{c}$.

8. Плеханова Т. Ф. Возделывание сахарной кукурузы / Т. Ф. Плеханова // Кукуруза и сорго. 1989. - № 2. - С. 47-48.

9. Сыпунов А. И. Основы возделывания сахарной кукурузы / А. И. Сыпунов. - М. : Росиздат, 2006. - 385 c

10. Циков B. C. Состояние и перспективы развития системы обработки почвы (обзор - исследования - опыт) / В. С. Циков. - Днепропетровск : ООО ЭНЭМ, 2008. - $56 \mathrm{c}$.

11. Циков В. С. Кукуруза на пищевые и лекарственные цели: производство, использование / В. С. Циков, Н. И. Конопля, С. В. Маслиёв. Луганск: «Шико», ООО «Виртуальная реальность», 2013. -232 с. 